\title{
WPLYW WYBRANYCH PARAMETRÓW SKRAWANIA NA DOKŁADNOŚĆ OBRÓBKI W PROCESIE WIERCENIA STOPU Ti6Al4V
}

\begin{abstract}
Wiercenie materiałów ciągliwych, do których zalicza się Ti6Al4V, często wiąże się z niewystarczającym odprowadzeniem wiórów, co prowadzi do wystąpienia zakłóceń procesu obróbki. Wióry powstające $\mathrm{w}$ trakcie procesu wiercenia materiałów plastycznych są ciągliwe i mają skłonność do gromadzenia się w rowkach wiórowych narzędzia. Takie gromadzenie się wiórów może skutkować zarysowaniami powierzchni otworu, przyklejeniami materiału do narzędzia skrawającego, a także do przyśpieszonego zużycia ostrza skrawającego. W niniejszym artykule przedstawiono wyniki badań uzyskane w procesie wiercenia stopu tytanu Ti6Al4V w aspekcie dokładności wymiarowo-kształtowej uzyskanych otworów. Obróbkę prowadzono bez chłodziwa (na sucho) przy różnych zestawach parametrów skrawania. W ramach badań monitorowano siłę posuwową i moment skrawania, dokładność kształtowo-wymiarową, jakość powierzchni otworu oraz kształt wiórów. Wyniki badań pokazują, że zarówno jakość otworu, jak i jego dokładność wymiarowokształtową można poprawić przez odpowiedni dobór parametrów skrawania. Ponadto, obserwacja powierzchni na wyjściu narzędzia $\mathrm{z}$ materiału wskazywała na występowanie odkształceń plastycznych (zadziory) związanych z parametrami skrawania. Wyniki eksperymentu wykazały także, że na kształt i wielkość zadziorów istotny wpływ ma prędkość posuwu.
\end{abstract}

Słowa kluczowe: wiercenie, siła posuwowa, moment skrawania, wióry, stop tytanu

\section{Wprowadzenie}

Stopy tytanu mają coraz większe spektrum zastosowań zarówno w przemyśle lotniczym, motoryzacyjnym, biomedycznym, jak i chemicznym dzięki doskonałej kombinacji wysokiej wytrzymałości właściwej (stosunek wytrzymałości do gęstości), odporności na pękanie i ogólnej odporności na korozję. Jednak stopy te są uważane za materiały trudnoobrabialne ze względu na ich wysoką wytrzymałość w podwyższonej temperaturze, stosunkowo niski moduł sprężystości, niskie przewodnictwo cieplne, wysoką aktywność chemiczną i mały współczynnik od-

\footnotetext{
1 Autor do korespondencji/corresponding author: Krzysztof Szwajka, Politechnika Rzeszowska, al. Powst. Warszawy 12, 35-959 Rzeszów, tel. 15844 8912, e-mail: kszwajka@prz.edu.pl

2 Joanna Zielińska-Szwajka, Politechnika Rzeszowska, e-mail: j.zielinska@ prz.edu.pl
} 
kształcenia [1-3]. Natomiast proces wiercenia jest uważany za jeden z najczęstszych procesów obróbki ze względu na fakt, że ma on zastosowanie do większości używanych stopów tytanu [4-6]. Przeprowadzono szereg badań dotyczących wiercenia stopu tytanu Ti6Al4V w odniesieniu do siły posuwowej, zużycia narzędzia skrawającego i jakości powierzchni otworu. Cantero i in. [7] przeprowadzili eksperyment polegający na obserwacji ewolucji zużycia narzędzi, jakości obrabianych otworów w procesie wiercenia stopu tytanu Ti6Al4V. Wiele eksperymentów dotyczących wiercenia tego stopu prowadzili Li i in. [8]. Miały one na celu ocenę wpływu materiału ostrza skrawającego, geometrii i parametrów procesu wiercenia na trwałość wiertła, siłę posuwową, moment skrawania i tworzenie zadziorów. Dornfeld i in. [9] wykazali, że zarówno posuw, jak i prędkość skrawania miały ograniczony wpływ na rozmiar zadziorów podczas wiercenia Ti6Al4V, chociaż można to przypisać ograniczonemu zakresowi prędkości skrawania $(6-10 \mathrm{~m} / \mathrm{min})$ i wartości posuwu $(0,04-0,20 \mathrm{~mm})$ zastosowanych w tych badaniach. Abdelhafeez i in. [4] prowadzili badania dotyczące analizy powierzchni otworu w celu identyfikacji wpływu prędkości skrawania i prędkości posuwu na wielkości zadziorów, średnicę otworu, a także na zużycie ostrza narzędzia skrawającego przy wierceniu stopów tytanu. Sun i in. [10] przeprowadzili badania dotyczące oceny jakości otworu po wierceniu, oparte na pomiarze średnicy otworu, okrągłości, wysokości zadziorów, średniej chropowatości powierzchni, mikrotwardości i morfologii wiórów. Pawar i in. [11] porównywali zużycie wierteł z węglików spiekanych przy wierceniu pakietów Ti, CFRP i CFRP/Ti osobno i analizowali wpływ przepływu wióra na jakość powierzchni otworu. Bono i Ni [12] opracowali model z zastosowaniem elementów skończonych i przeprowadzili eksperymentalne badanie wpływu odkształceń termicznych na średnicę i walcowość wywierconych otworów. Okazało się, że dominującym efektem była termiczna ekspansja wiertła, która prowadziła do zwiększenia średnicy otworu wraz ze wzrostem głębokości wiercenia. Prasanna i in. [13] przeprowadzili eksperyment na optymalizacji parametrów procesowych wiercenia na sucho dla małych otworów w Ti6A14V za pomocą metody Taguchi i teorii szarych systemów. Wyniki tych badań wykazały, że prędkość obrotowa wrzeciona ma największy wpływ na dokładność wymiarową otworu. Poza tym niektórzy badacze skupili się na analizie powstawania zadziorów w procesie wiercenia [14-17].

\section{Metodyka badań}

W badaniach jako materiał obrabiany zastosowano stop tytanu Ti6Al4V o składzie chemicznym (wg ASTM F1108) przedstawionym w tab. 1. Natomiast w tabeli 2. ukazano własności fizyczne (wg ASTM F1108) oraz mikrostrukturę stopu Ti6Al4V. 
Tabela 1. Skład chemiczny stopu Ti6Al4V

Table 1. Chemical composition of Ti6Al4V

\begin{tabular}{|c|c|c|c|c|c|c|c|c|}
\hline Jednostka & Ti & Al & V & Fe & C & N & H & O \\
\hline$\%$ & baza & $5,5-6,75$ & $3,5-4,5$ & $<0,25$ & $<0,08$ & $<0,05$ & $<0,01$ & $<0,2$ \\
\hline
\end{tabular}

Tabela 2. Własności fizyczne stopu i mikrostruktura materiału Ti6Al4V

Table 2. Physical property of Ti6Al4V and SEM micrograph of the material workpiece

\begin{tabular}{|l|c|c|c|}
\hline Gęstość & $\left(\mathrm{kg} / \mathrm{m}^{3}\right)$ & 4430 & \multirow{3}{*}{} \\
\hline Temperatura topienia & $\left({ }^{0} \mathrm{C}\right)$ & 1668 \\
\hline Przewodność cieplna & $\left(\mathrm{W} / \mathrm{m}^{0} \mathrm{C}\right)$ & 7,3 \\
\hline Granica plastyczności & $(\mathrm{MPa})$ & 820 \\
\hline Moduł Younga & $(\mathrm{GPa})$ & 113,8 & \\
\hline Współczynnik Poissona & - & 0,342 & \\
\hline Ciepło właściwe & $\left(\mathrm{J} /\left(\mathrm{kg} /{ }^{0} \mathrm{C}\right)\right)$ & 526 & \\
\hline
\end{tabular}

W ramach przeprowadzonych prób wiercono otwory w płaskowniku Ti6Al4V o wymiarach $130 \times 22 \times 12 \mathrm{~mm}$. Jako narzędzie skrawające zastosowano (na podstawie literatury, zastosowań przemysłowych i zaleceń producenta narzędzia) wiertło spiralne o średnicy $\phi=6,1 \mathrm{~mm}$, wykonane $\mathrm{z}$ węglika spiekanego, o kącie wierzchołkowym $2 \kappa_{r}=140^{\circ}$ i kącie pochylenia linii śrubowej rowka $\lambda=35^{0}$, pokrywane TiAlN metodą PVD. W tabeli 3. pokazano podstawowe wymiary zastosowanego narzędzia skrawającego firmy ISCAR (SCD 061-043-080 ACP5N) oraz parametry skrawania stosowane w badaniach.

Tabela 3. Narzędzie skrawające i parametry skrawania

Table 3. Drill information and cutting parameters

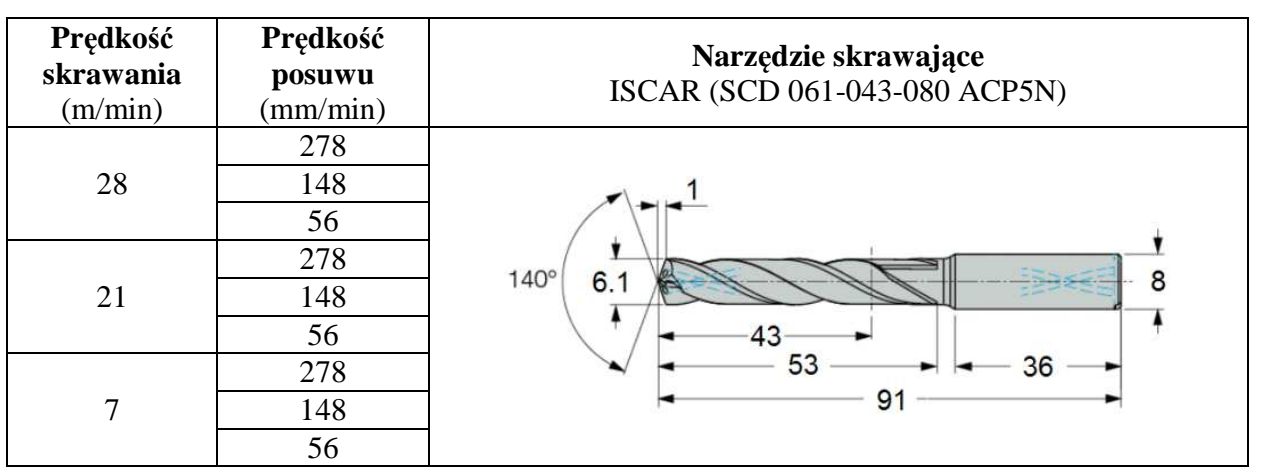

Proces wiercenia przeprowadzono na frezarce pionowej firmy EMCO, będącej na wyposażeniu laboratorium Wydziału Mechaniczno-Technologicznego Politechniki Rzeszowskiej. Badania prowadzono bez użycia chłodziwa, z uwagi na 
możliwość uzyskania widocznego obrazu procesu tworzenia się wióra w trakcie prowadzonej obróbki. Na rysunku 2. przedstawiono stanowisko badawcze w trakcie prowadzonych eksperymentów.

$\mathrm{W}$ realizowanych badaniach rejestrowano dodatkowo (w celach poznawczych) sygnały siły posuwowej $\left(F_{f}\right)$ i momentu skrawania $\left(M_{c}\right)$ pochodzące ze strefy skrawania w trakcie obróbki stopu Ti6Al4V. Schematyczny diagram konfiguracji systemu archiwizacji danych pomiarowych przedstawiono na rys. 3 .

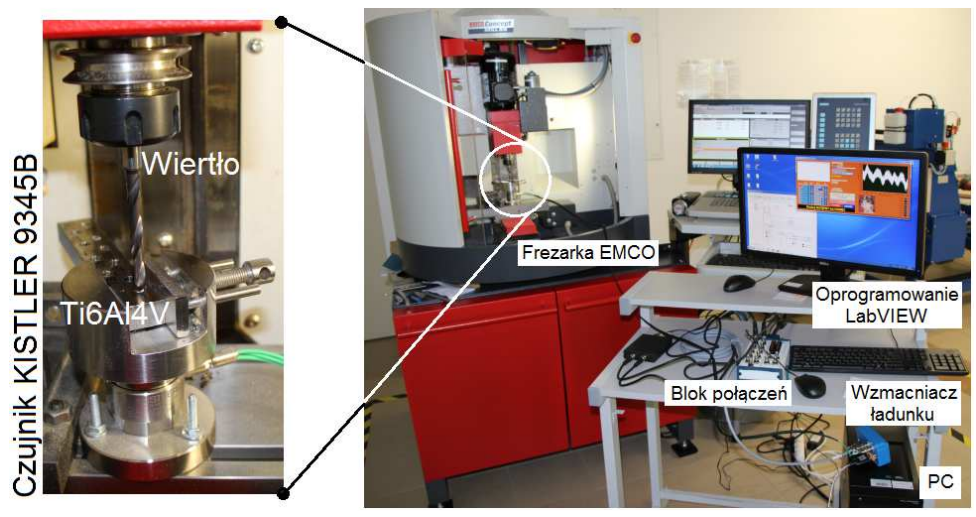

Rys. 2. Stanowisko badawcze

Fig. 2. Experimental set-up

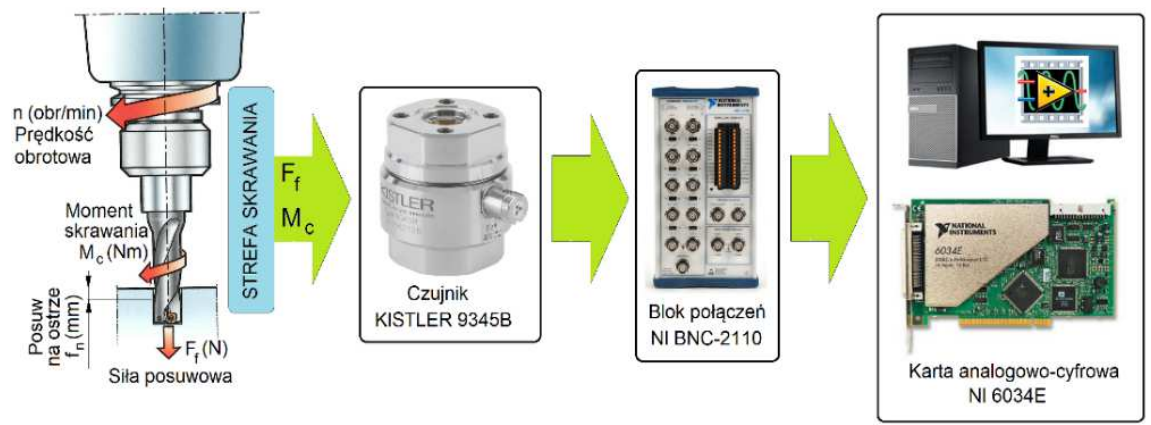

Rys. 3. Tor pomiarowy wraz z systemem akwizycji danych

Fig. 3. Experimental set-up and schematic of data acquisition system

Wielkości fizyczne $\left(F_{f}\right.$ i $\left.M_{c}\right)$ były mierzone za pomocą piezoelektrycznego czujnika przemysłowego KISTLER 9345B2. Sygnały napięciowe pochodzące z czujnika rejestrowano na dysku komputera osobistego (PC) w postaci cyfrowej, za pośrednictwem umieszczonej wewnątrz PC karty analogowo-cyfrowej NI 6034E. Częstotliwość próbkowania sygnałów pochodzących ze strefy skrawania podczas prowadzonych eksperymentów wynosiła $50 \mathrm{kHz}$ na kanał, a rozdzielczość pomiarowa karty - 16 bitów. 
Przeprowadzone badania zostały zaprojektowane w celu zbadania wpływu prędkości skrawania $\left(v_{c}\right)$, prędkości posuwu $\left(v_{f}\right)$ na: wartość siły posuwowej i momentu skrawania, dokładność kształtową i jakość powierzchni wykonanych otworów oraz proces tworzenia się i kształt powstałych wiórów. Średnicę otworu mierzono za pomocą mikroskopu pomiarowego MITUTOYO TM505B (rys. 4b) oraz sensora krawędziowego 3D o rozdzielczości $0,005 \mathrm{~mm}$ i średnicy kulki pomiarowej $2 \mathrm{~mm}$ (rys. 4a).
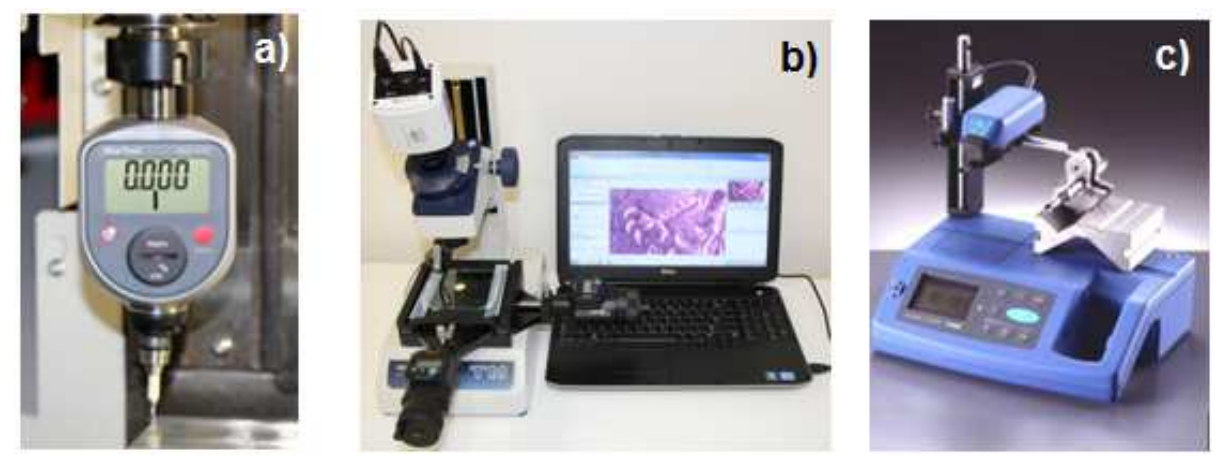

Rys. 4. Pomiar kształtu i chropowatości powierzchni: a) sensor krawędziowy 3D, b) mikroskop pomiarowy, c) profilometr

Fig. 4. Measurement of the shape and surface roughness: a) edge sensor 3D, b) measuring microscope, c) profilometer

Chropowatości powierzchni mierzono za pomocą profilometru HommelTESTER T1000 (rys. 4c). W celu dogodniejszego dostępu do realizacji pomiaru chropowatości powierzchni na długości otworu przecięto materiał obrabiany na dwie części.

W trakcie przeprowadzonych badań wykonano serię otworów z parametrami skrawania przedstawionymi w tab. 3. Dla każdego zestawu parametrów przeprowadzono trzy powtórzenia, na podstawie których została wyznaczona wartość średnia arytmetyczna dla wszystkich analizowanych parametrów. Na rysunku 5. przedstawiono wielkości geometryczne skrawania wraz z ich oznaczeniem, stosowane w trakcie badań.

Rys. 5. Wielkości geometryczne warstwy skrawanej przy wierceniu: $f_{z}$ - posuw na ostrze $(\mathrm{mm}), A_{c}$ - pole przekroju warstwy skrawanej $\left(\mathrm{mm}^{2}\right)$

Fig. 5. Geometric quantities of the cutting layer in drilling: $f_{z}$ - feed per tooth $(\mathrm{mm}), A_{c}-$ cross-sectional area of the cutting layer $\left(\mathrm{mm}^{2}\right)$

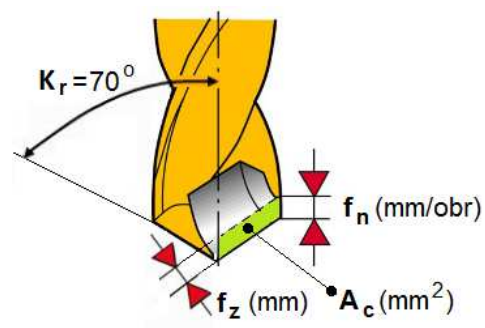




\section{Wyniki badań}

Podczas wiercenia wiertłem spiralnym $\mathrm{z}$ węglika, gdy narzędzie wnika w materiał, zamiast skrawania ostrze wiertła dociska materiał. Rysunek 6. ilustruje zmienności siły posuwowej i momentu skrawania w funkcji głębokości wiercenia (czasu skrawania) w trakcie wiercenia stopu tytanu Ti6Al4V, przy prędkości skrawania $21 \mathrm{~m} / \mathrm{min}$ i prędkości posuwu $148 \mathrm{~mm} / \mathrm{min}$. Zauważono, że podczas wiercenia występują trzy główne obszary zmienności wartości siły posuwowej. Region 1. określa okres, w którym wiertło przebyło odległość $h$ równą wysokości ostrzy skrawających wiertła. Dla wiertła użytego w tym badaniu $h=1 \mathrm{~mm}$ (tab. 1.). Gdy tylko krawędź ostrza wejdzie w materiał, siła posuwowa rośnie gwałtownie i osiąga wartość największą (1020 N) na końcu regionu 1. Stała siła posuwowa pojawiła się, gdy krawędzie tnące wiertła zagłębiły się w materiale obrabianym, jak pokazano w regionie 2 . Siła posuwowa spadła do zera w regionie 3., gdy krawędzie skrawające wiertła opuściły element obrabiany. Dodatkowo można zaobserwować dodatnią (niewielką co do wartości) siłę posuwową po wyjęciu wiertła $\mathrm{z}$ obrabianego przedmiotu, w wyniku zakleszczenia się wiórów w otworze. Na rysunku 7. pokazano przebieg wartości siły posuwowej i momentu skrawania zarejestrowanej w trakcie wiercenia stopu tytanu Ti6Al4V w funkcji pola powierzchni nominalnego przekroju warstwy skrawanej $\left(A_{c}\right)$.

Można więc zauważyć, że zarówno wartość siły posuwowej, jak i momentu skrawania podczas wiercenia stopu tytanu Ti6Al4V rośnie $\mathrm{w}$ stosunku do pola przekroju warstwy skrawanej. W przypadku siły posuwowej wzrost ten wynosi powyżej $400 \%$, natomiast dla momentu skrawania wynosi on około $500 \%$ przy ponad 10-krotnym wzroście przekroju warstwy skrawanej, z czym wiąże się większą objętość usuwanego (skrawanego) materiału. Ponadto stwierdzono, że prędkość skrawania nie ma wpływu na wartość siły posuwowej oraz momentu skrawania.

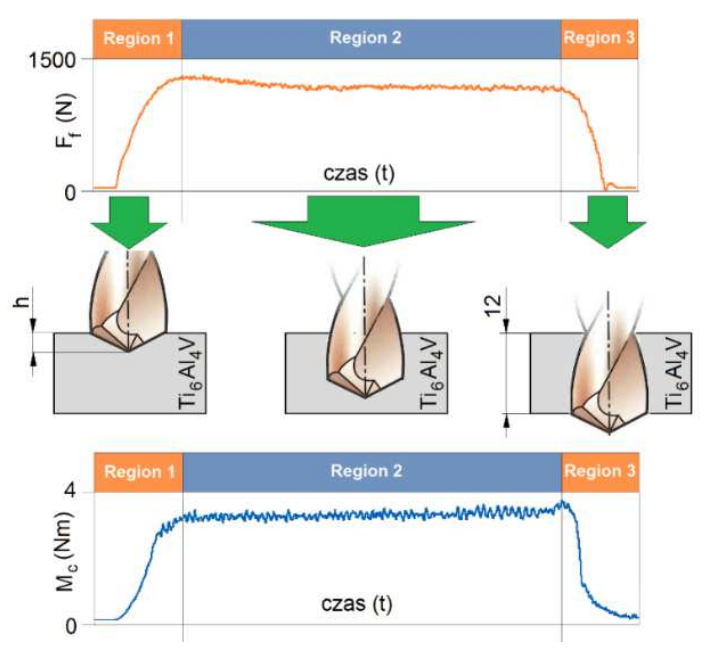

Rys. 6. Przebieg siły posuwowej i momentu skrawania podczas wiercenia

Fig. 6. Thrust force cutting torque in drilling 


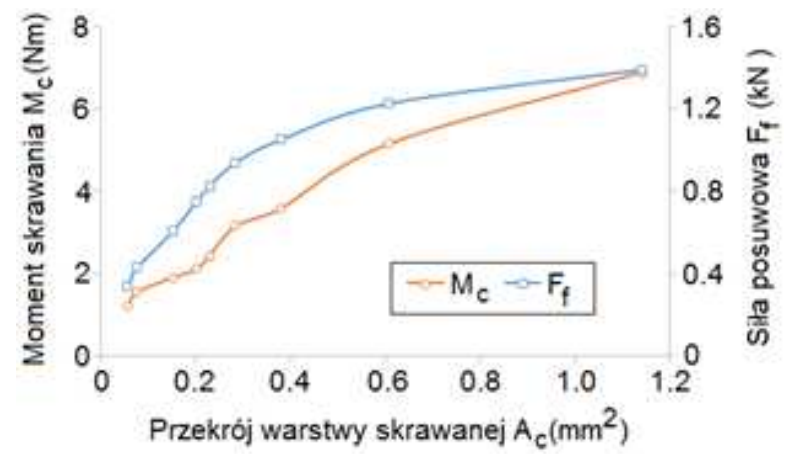

Rys. 7. Przebieg wartości siły posuwowej $\left(F_{f}\right)$ i momentu skrawania $\left(M_{c}\right)$ zarejestrowanej w trakcie wiercenia stopu tytanu Ti6Al4V w funkcji pola powierzchni przekroju warstwy skrawanej $\left(A_{c}\right)$

Fig. 7. The course of the values of the feed force $\left(F_{f}\right)$ and the cutting moment $\left(M_{c}\right)$ recorded during the drilling of Ti6Al4V titanium alloy as a function of the cross-sectional area of the cutting layer $\left(A_{c}\right)$

Tworzenie się zadziorów podczas wiercenia jest niepożądanym zjawiskiem ze względu na trudność ich całkowitego usunięcia. Szacuje się, że do 30\% kosztów typowych komponentów jest spowodowane gratowaniem. Zadziory powstaja w wyniku odkształcenia plastycznego i propagacji pęknięć na etapie wyjścia ostrzy narzędzia skrawającego $\mathrm{z}$ materiału obrabianego $\mathrm{w}$ procesie wiercenia. Ostateczna morfologia zadziorów jest określona przez wielkość plastycznego odkształcenia oraz mechanikę pękania obrabianego materiału. Dlatego o mechanizmie powstawania zadziorów, oprócz parametrów skrawania, decydują w głównej mierze właściwości obrabianego materiału. $\mathrm{W}$ badaniach zaobserwowano istnienie trzech form powstawania zadziorów podczas wiercenia, jak pokazano na rys. 8 .

Gdy ostrza wiertła zbliżają się do wyjścia z przedmiotu obrabianego, jak pokazano na rys. 8a, zwiększa się plastyczne odkształcenie pozostałego jeszcze do usunięcia materiału. Pozostały materiał może zatem zostać przecięty lub wypchnięty pod działaniem siły posuwowej. W takich warunkach wiercenia, gdy przekroczymy wartość wytrzymałości obrabianego materiału na odkształcenia plastyczne, w miejscu wiercenia zostaje zainicjowane zjawisko pękania. W związku z tym na powierzchni wyjścia narzędzia z otworu rzadko kiedy następuje inicjalizowanie zjawiska powstawania zadziorów, jak pokazano na rys. 8d. Jeśli odkształcenie plastyczne będzie kontynuowane jeszcze przy wyjściu ostrzy wiertła z materiału, mogą wystąpić dwa rodzaje pęknięć pokazanych na rys. 8b, 8c. Pierwszy przypadek - gdy pęknięcie nastąpiło wzdłuż krawędzi wyjściowej otworu, a drugi - w pobliżu osi wiertła. W pierwszym przypadku „czapki” i zadziory zostały uformowane równomiernie, jak pokazano na rys. 8e. Ta część 


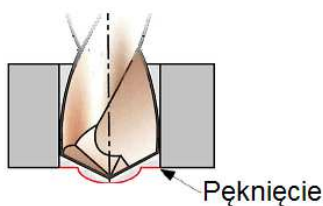

(a)

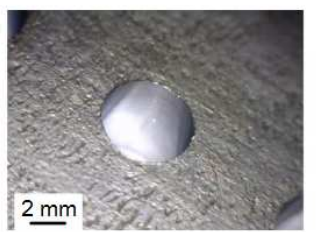

(d)

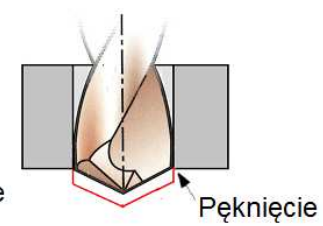

(b)

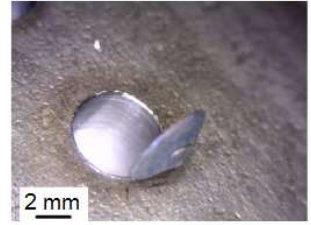

(e)

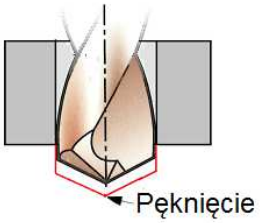

(c)

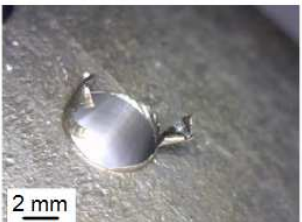

(f)

Rys. 8. Miejsce pęknięcia w materiale obrabianym na wyjściu narzędzia: (a) pęknięcie powstałe przed wyjściem ostrzy wiertła z otworu, (b) pęknięcie powstałe wzdłuż krawędzi wyjściowej otworu, (c) pęknięcie powstałe po wyjściu ostrzy wiertła $\mathrm{z}$ otworu, (d) zadziory $\mathrm{z}$ pęknięciem powstałym przed wyjściem ostrzy wiertła z materiału obrabianego, (e) zadziory z pęknięciem powstałym wzdłuż krawędzi wyjściowej otworu, (f) zadzior z pęknięciem powstałym po wyjściu ostrzy z materiału obrabianego.

Fig. 8. Crack location in burr formation (a) crack at drill point before drill exits hole, (b) crack along the exit edge of the hole, (c) crack at drill point after drill exits hole, (d) burr with crack at drill point before drill exits hole, (e) burr with crack along the exit edge of the hole, (f) burr with crack at drill point after drill exits hole

wzdłuż krawędzi otworu była poddawana równomiernym naprężeniom rozciągającym. Jeśli pęknięcie zaczyna się w okolicach osi wiertła, ,czapka” może zostać rozerwana na kilka części i pozostać jako zadziory, które są duże i nieregularne, jak pokazano na rys. 8f. Dlatego też rodzaj tworzenia zadziorów jest określany przez początkowe miejsce pęknięcia materiału, które zależy od wartości odkształcenia plastycznego. Wielkość zadziorów zależy również od pozostałej do usunięcia warstwy skrawanej i miejsca inicjalizacji pęknięcia.

Na rysunku 9. przedstawiono przebieg zmian wysokości zadziorów $\left(h_{c}\right)$ w funkcji prędkości posuwu $\left(v_{f}\right)$.

Odchylenie od nominalnego wymiaru średnicy otworu jest ważnym wskaźnikiem szeroko stosowanym w przemyśle do oceny dokładności wymiarowej wierconych otworów. Wpływ prędkości skrawania i posuwu na średnicę otworu jest skomplikowany ze względu na ich wzajemne oddziaływanie. Z jednej strony plastyczność obrabianego materiału powiązana z naciskiem występującym od siły posuwowej, z drugiej strony duża ilość ciepła wytworzonego w trakcie skrawania oraz trudności z odprowadzeniem wiórów mogą być przyczyną zwiększenia średnicy otworu. 

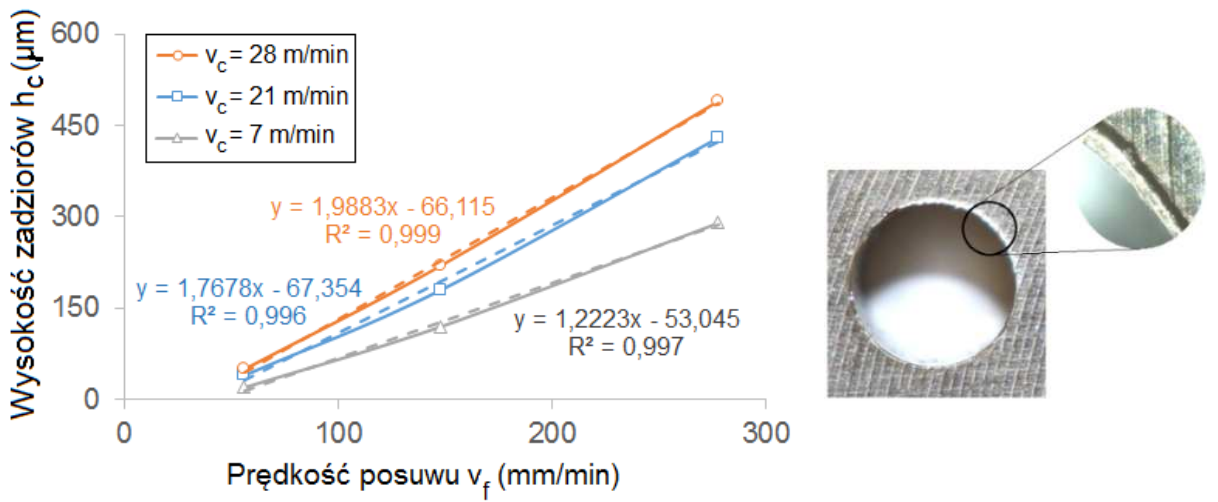

Rys. 9. Wysokość zadziorów w funkcji prędkości posuwu dla trzech prędkości skrawania

Fig. 9. Burr height as a function of feed speed for three cutting speed

Na podstawie rysunku 10. można stwierdzić, że wszystkie średnice otworów były przewymiarowane, a błędy średnicy wahały się od 12 do $89 \mu \mathrm{m}$. Potwierdza to, że ciepło generowane w procesie wiercenia może prowadzić do rozszerzalności cieplnej wiertła i przedmiotu obrabianego, czego skutkiem są zbyt duże średnice otworów. Dlatego oczywiste jest, że wpływ z rozszerzania się otworów przeważa nad efektem skurczu przedmiotu obrabianego.

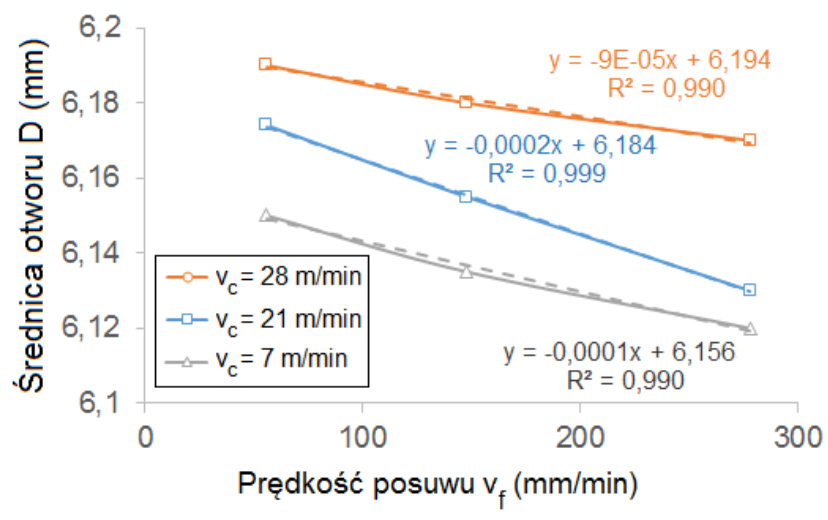

Rys. 10. Średnice otworów w funkcji parametrów skrawania

Fig. 10. Diameter of holes as a function of cutting parameters

Pomiar okrągłości dostarcza informacji na temat kształtu otworu, szczególnie w odniesieniu do tego, w jaki sposób okrągły przekrój otworu jest zbliżony do rzeczywistego okręgu. Okrągłość otworu to dwuwymiarowa tolerancja geometryczna, która pozwala określić, jak wiele cech może odbiegać od idealnego 
koła. Zmierzono 8 punktów zorientowanych na powierzchni otworu. Wyniki pomiaru okrągłości zaprezentowano na rys. 11. Na podstawie danych pomiarowych można zauważyć, że maksymalne odchyłki w zakresie okrągłości otworu wynosiły do $16 \mu \mathrm{m}$. To pokazuje, że lepszą dokładność otworu można uzyskać przy wyższej prędkości skrawania i małym posuwie. Można to wytłumaczyć faktem, że odkształcenie plastyczne materiału obrabianego zwiększa się wraz ze wzrostem prędkości posuwu.

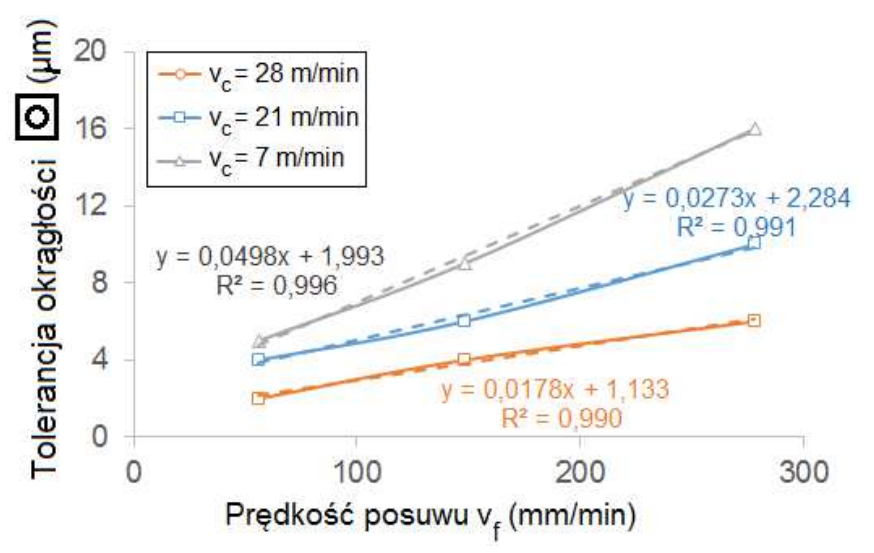

Rys. 11. Tolerancja okrągłości w funkcji parametrów skrawania

Fig. 11. Roundness tolerance as a function of cutting parameters

Zdolność łamania wiórów jest definiowana jako liczba segmentów w 100 g wiórów [2]. Łamanie wióra na segmenty w przypadku możliwego rozwiązania polegałoby na zwiększeniu grubości warstwy skrawanej. Jednak wartość pola przekroju warstwy skrawanej zależy od wartości prędkości posuwu $\left(v_{f}\right)$. Na rysunku 12. pokazano typową makroskopową postać wiórów tworzących się przy wierceniu stopu tytanu Ti6Al4V w zależności od prędkości skrawania i posuwu.

Zauważono, że na postać wiórów duży wpływ ma wartość posuwu na ostrze $\left(f_{z}\right)$. Dla posuwu $\left(f_{z}\right)$ z zakresu $0,19-0,37 \mathrm{~mm}$ wióry są podatne na łamanie na małe segmenty. Gdy wartość posuwu zmienia się z 0,19 do $0,37 \mathrm{~mm}$, średnia długość wióra zmniejsza się z 45 do $15 \mathrm{~mm}$. Zwiększenie wartości posuwu sprzyja powstawaniu nieciągłych wiórów. Może to wynikać z faktu, że wraz ze wzrostem posuwu zwiększa się sztywność wióra (zwiększa się powierzchnia przekroju wióra). W tym przypadku widać również, że wpływ prędkości skrawania na kształt i wielkość wiórów jest mniejszy w porównaniu do posuwu. Prędkość skrawania nie odgrywa żadnej roli w łamliwości wiórów, a wióry o tej samej długości są obserwowane dla wszystkich prędkości skrawania. Warto wspomnieć, że wióry mogą być splątane wokół dwóch rowków wiórowych wiertła, gdy posuw jest niewielki $(0,02 \mathrm{~mm})$. To splątanie wiórów wynika z trudności płynnego wyrzucania wiórów z rowków wiórowych wiertła. 


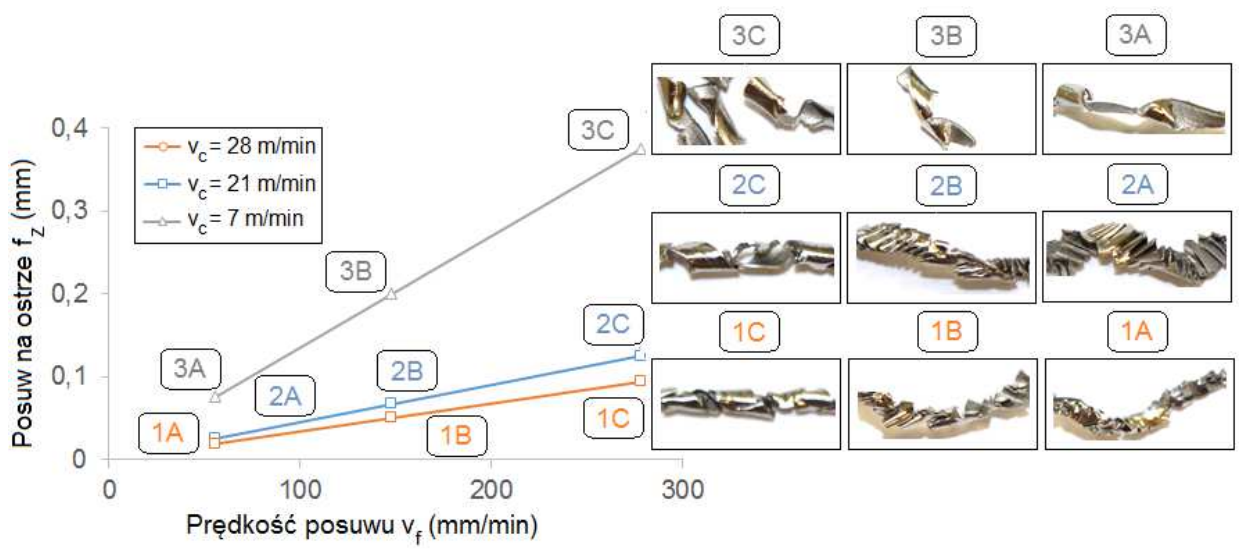

Rys. 12. Zaobserwowany kształt wiórów w trakcie wiercenia stopu tytanu Ti6Al4V

Fig. 12. Observed shape of chips during drilling of Ti6Al4V titanium alloy

Topografia powierzchni jest jedną z głównych cech branych pod uwagę w celu oceny jakości cięcia w procesach obróbki skrawaniem. Rysunek 13. pokazuje przykładową mapę topograficzną powierzchni przekroju wywierconego otworu. Na podstawie map topografii, można zauważyć, że jakość otworu była najgorsza w przypadku najniższej prędkości skrawania $7 \mathrm{~m} / \mathrm{min}$ i posuwu $0,2 \mathrm{~mm}$. Średnia chropowatość powierzchni $(R a)$ wynosiła 5,3 $\mu \mathrm{m}$. Zaobserwowano również kilka równoległych rowków na ścianie otworu, jak pokazano na rys. 13. Te równoległe rowki zmniejszały się stopniowo wraz ze wzrostem prędkości skrawania i zmniejszeniem posuwu. W miarę zwiększania prędkości skrawania, przy jednoczesnym zmniejszeniu posuwu zaobserwowano poprawę chropowatości powierzchni. W przypadku prędkości skrawania $21 \mathrm{~m} / \mathrm{min}$ i posuwu $0,07 \mathrm{~mm}$ średnia chropowatość powierzchni $(R a)$ wynosiła $3,8 \mu \mathrm{m}$, dla prędkości skrawania $28 \mathrm{~m} / \mathrm{min}$ i posuwu $0,05 \mathrm{~mm}$ średnia chropowatość powierzchni $(R a)$ wynosiła $3,1 \mu \mathrm{m}$. Można to wytłumaczyć faktem, że nagromadzenie wióra w rowkach

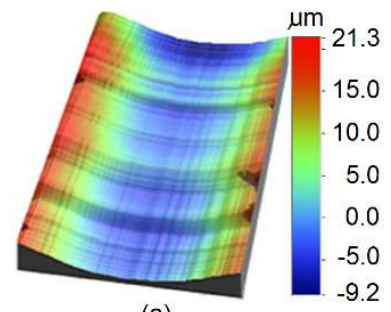

(a)

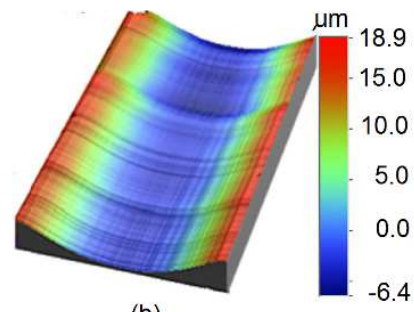

(b)

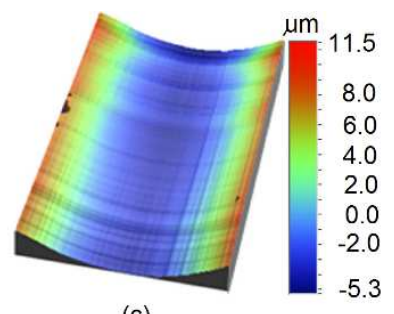

(c)

Rys. 13. Topografia powierzchni otworów dla różnych parametrów skrawania: a) $v_{c}=7 \mathrm{~m} / \mathrm{min}$, $\left.f_{z}=0,2 \mathrm{~mm}, \mathrm{~b}\right) v_{c}=21 \mathrm{~m} / \mathrm{min}, f_{z}=0,07 \mathrm{~mm}$, c) $v_{c}=28 \mathrm{~m} / \mathrm{min}, f_{z}=0,05 \mathrm{~mm}$

Fig. 13. Topography of the surface for different cutting parameters: a) $v_{c}=7 \mathrm{~m} / \mathrm{min}, f_{z}=0,2 \mathrm{~mm}$, b) $\left.v_{c}=21 \mathrm{~m} / \mathrm{min}, f_{z}=0,07 \mathrm{~mm}, \mathrm{c}\right) v_{c}=28 \mathrm{~m} / \mathrm{min}, f_{z}=0,05 \mathrm{~mm}$ 
wiórowych malało wraz ze wzrostem prędkości skrawania. Dzięki temu można uzyskać lepszą topografię powierzchni dla wyższej prędkości skrawania i małej wartości posuwu.

\section{Wnioski}

W artykule przeprowadzono serię prób wiercenia na sucho stopu Ti6Al4V, mających na celu analizę: siły posuwowej, momentu skrawania, wielkości powstałych zadziorów, chropowatości powierzchni otworów oraz postaci tworzenia się wióra. Na podstawie uzyskanych wyników można stwierdzić, że:

1. Zarówno wartość siły posuwowej $\left(F_{f}\right)$, jak i momentu skrawania $\left(M_{c}\right)$ jest ściśle związana z wartością przekroju warstwy skrawanej $\left(A_{c}\right)$, która jest powiązana $\mathrm{z}$ wartością prędkości posuwu $\left(v_{f}\right)$. Wartość siły posuwowej wzrosła ponad 4-krotnie w odniesieniu do przekroju warstwy skrawanej $\left(A_{c}\right)$, którego pole powierzchni zostało zwiększone z 0,018 do $0,375 \mathrm{~mm}^{2}$. Wartość momentu skrawania wzrosła ponad 5-krotnie w odniesieniu do przekroju warstwy skrawanej $\left(A_{c}\right)$, którego pole powierzchni zostało zwiększone z 0,018 do $0,375 \mathrm{~mm}^{2}$.

2. Powstawanie oraz kształt zadziorów są określane przez początkowe miejsce pęknięcia materiału, które zależy od wartości odkształcenia plastycznego. Wielkość zadziorów zależy również pośrednio od pozostałej do usunięcia warstwy skrawanej i miejsca inicjalizacji pęknięcia. W zakresie badanych parametrów skrawania zauważono, że wysokość zadziorów $\left(h_{c}\right)$ jest najbardziej zależna od posuwu, w nieco mniejszym stopniu od prędkości skrawania.

3. Kształt i wielkość wiórów są silnie uzależnione od wartości posuwu. Aby zapewnić poprawny przebieg procesu wiercenia i późniejszego zautomatyzowanego montażu, wióry należy rozbić na segmenty. Wyniki eksperymentalne wskazują, że wiercenie z posuwem z przedziału od 0,2 do $0,3 \mathrm{~mm}$ daje wióry segmentowe.

4. Większą dokładność w zakresie tolerancji okrągłości wykonania otworu można uzyskać przy wyższej prędkości skrawania i małym posuwie.

5. Chropowatość powierzchni była znacznie mniejsza dla większych prędkości skrawania i małej wartości posuwu.

\section{Literatura}

[1] Ren N., Jiang L., Liu D., Lv L., Wang Q.: Comparison of the simulation and experimental of hole characteristics during nanosecond-pulsed laser drilling of thin titanium sheets, Int. J. Adv. Manuf. Technol., 76 (2014) 735-743.

[2] Shetty P.K., Shetty R., Shetty D., Rehaman N.F., Jose T.K.: Machinability study on dry drilling of titanium alloy Ti-6Al-4V using L9 orthoganal array, Procedia Mater. Sci., 5 (2014) 2605-2614. 
[3] Shyha I.S., Soo S.L., Aspinwall D.K., Bradley S., Perry R., Harden P., Dawson S.: Hole quality assessment following drilling of metallic-composite stacks, Int. J. Tools Manuf., 51 (2011) 569-578.

[4] Abdelhafeez A.M., Soo S.L., Aspinwall D.K., Dowson A, Arnold D.: Burr formation and hole quality when drilling titanium and aluminium alloys, Procedia CIRP, 37 (2015) 230-235.

[5] Bi S., Liang J.: Experimental studies and optimization of process parameters for burrs in dry drilling of stacked metal materials. Int J. Adv. Manuf. Technol., 53 (2010) 867-876.

[6] Nouari M., List G., Girot F., Géhin D.: Effect of machining parameters and coating on wear mechanisms in dry drilling of aluminium alloys, Int. J. Tools Manuf., 45 (2005) 1436-1442.

[7] Cantero J.L., Tardío M.M., Canteli J.A., Marcos M., Miguélez M.H.: Dry drilling of alloy Ti-6Al-4V, Int. J. Tools Manuf., 45 (2005) 1246-1255.

[8] Li R., Hegde P., Shih A.J.: High-throughput drilling of titanium alloys. Int. J. Tools Manuf., 47 (2007) 63-74.

[9] Dornfeld D.A., Kim J.S., Dechow H, Hewson J, Chen L.J.: Drilling burr formation in titanium alloy Ti-6AI-4V, CIRP Ann-Manuf. Technol., 48 (1999) 73-76.

[10] Sun J., Guo Y.B.: A new multi-view approach to characterize 3D chip morphology and properties in end milling titanium Ti-6Al-4V, Int. J. Tools Manuf., 48 (2008) 1486-1494.

[11] Pawar O.A., Gaikhe Y.S., Tewari A., Sundaram R., Joshi S.S.: Analysis of hole quality in drilling GLARE fiber metal laminates, Compos. Struct., 123 (2015) 350-365.

[12] Bono M., Ni J.: The effects of thermal distortions on the diameter and cylindricity of dry drilled holes. Int. J. Tools Manuf., 41 (2001) 2261-2270.

[13] Prasanna J., Karunamoorthy L., Venkat Raman M., Prashanth S., Raj Chordia D.: Optimization of process parameters of small hole dry drilling in Ti-6Al-4V using Taguchi and grey relational analysis, Measurement, 48 (2014) 346-354.

[14] Hsu I., Tsao C.C.: Study on the effect of frequency tracing in ultrasonic-assisted drilling of titanium alloy, Int. J. Adv. Manuf. Technol., 43 (2008) 127-135.

[15] Ko S., Chang J., Yang G.: Burr minimizing scheme in drilling, J. Mater. Process Technol., 140 (2003) 237-242.

[16] Ko S., Lee J.: Analysis of burr formation in drilling with a new-concept drill, J. Mater. Process. Technol., 113 (2001) 392-398.

[17] Lei S., Liu W.J.: High-speed machining of titanium alloys using the driven rotary tool, Int. J. Tools Manuf., 42 (2002) 653-661.

[18] Denkena B., Boehnke D., Dege J.H.: Helical milling of CFRP-titanium layer compounds, CIRP J. Manuf. Sci. Technol., 1 (2008) 64-69. 


\section{Podziękowania}

Badania zostały przeprowadzone przy użyciu sprzętu badawczego zakupionego w ramach projektu „Utworzenie Międzyuczelnianego Laboratorium Naukowo-Badawczego w Stalowej Woli" w ramach Programu Operacyjnego Rozwój Polski Wschodniej 2007-2013, Oś priorytetowa I Nowoczesna gospodarka, Działanie 1.3, umowa nr POPW.01.03.00-18-016/12-00.

\section{EFFECT OF CUTTING PARAMETERS IN THE ASPECT OF THE ACCURACY OF DRILLING PROCESSING TITANIUM ALLOYS TI6AI4V}

\section{S u m m a r y}

The drilling of ductile materials, such as Ti6Al4V, is often associated with insufficient chip evacuation, resulting in disturbances in the machining process. Chips formed during the drilling process of plastic materials are ductile and tend to accumulate in the chip flutes of the tool. Such chip formation may result in scratches on the hole surface, sticking the material to the cutting tool, and also on accelerated wear of the cutting edge. This article presents the analysis of the drilling process and assessment of the quality of the hole after drilling Ti6Al4V titanium alloy without coolant at various processing parameters. As part of the research, the feed force and cutting moment were monitored, the shape and dimensional accuracy and the quality of the hole surface and the shape of the chips. The test results show that the hole quality can be improved by appropriate selection of cutting parameters. Observation of the surface at the exit of the tool from the material indicated plastic deformation (burrs) in different cutting conditions. The results of the experiment also showed that the shape and size of burrs is strongly influenced by the feed speed.

Keywords: drilling, feed force, cutting moment, chips, titanium alloy

DOI: $10.7862 / \mathrm{rm} .2019 .07$

Otrzymano/received: 17.09.2018 $r$.

Zaakceptowano/accepted: 16.11.2018 r. 